\title{
Rhyme, Rhythm and Rhetoric in Religious Discourse in Nigeria's ESL Environment
}

\author{
Dare Owolabi ${ }^{1}$ \\ ${ }^{1}$ Department of English and Literary Studies, Ekiti State University, Ado Ekiti, Nigeria \\ Correspondence: Dare Owolabi, Department of English and Literary Studies, Ekiti State University, Ado Ekiti, \\ Nigeria. Tel: 234-803-608-2786. E-mail: dareowo2006@yahoo.com
}

Received: July 4, $2012 \quad$ Accepted: August 9, $2012 \quad$ Online Published: August 30, 2012

doi:10.5539/ijel.v2n5p1

URL: http://dx.doi.org/10.5539/ijel.v2n5p1

\begin{abstract}
This study documents the ingenious use of the English language in a second language environment, in a way that is making Nigerian preachers who use English as a medium of communication almost becoming more catholic than the Pope. The method used was the researcher's observation as a participant in the places where the sermons where the data were drawn from were preached. This is in addition to reading various Christian literatures and documenting the observed ingenious use of the English language in a non-native environment. Data gathered were analyzed based on stylistic and pragmatic techniques. The results showed that the English language is gradually taking on a life of its own in Nigeria, especially in the way words are selected, coined and manipulated, in addition to the systematic structural arrangement of points and ideas in sermons to make them rhythmical, rhetorical and memorable. From the way the English language is used as discussed in this study, from both literary and linguistic points of view, making recourse to speech act theories, it is obvious that the English language is becoming a servant in Nigeria. Nigerian second language English users are now showing a mastery of the language and giving it a Nigerian identity, while adopting it to suit their peculiar purpose.
\end{abstract}

Keywords: rhyme, rhythm, rhetoric, literary consideration, pragmatism, stylistics, ESL environment

\section{Introduction}

Nigeria, one of the largest populations of speakers of English as second language in the world (Akere, 2009; Jowitt, 2009), now uses the language with some measure of dexterity that may soon amaze native speakers. With its teeming population of diverse ethnic nationalities, Nigeria is a secular nation, but with many religious inclinations. There is also religious polarity in the country, with the Muslim faithful to the north and the Christian faithful to the south. This is, however, without the admixture of traditional worshippers found in different parts of the country. The adherents of Islamism still worship largely in the Arabic language, the Christians in various indigenous languages, but English is a common linguistic denominator in major cities where we have a conglomerate of different nationalities. In the case of traditional religions, prevalent in different parts of the country, the indigenous language of the adherents still remains the linguistic mode of worship, as some of the religious tenets are still largely secret. This study is restricted to the use of English in Christian religious worship, especially as found in many Nigerian churches in cities. It is the common practice to find messages preached in the English language and then translated into indigenous languages, even when the preacher and the congregation understand the indigenous languages very well.

Language is a human phenomenon that is crucial in all human endeavors. As a primary means of communication, it is a tool for carrying out many human activities and performing informative, persuasive, entertaining and suggestive roles in the society. Language can also be used as a means of prevarication, the mischievous use to which many deploy it. The specific purpose of language will determine the style to be adopted by the user to suit the audience. In other words, there is no uniformity in the use to which language is deployed, and this is what accounts for different varieties of language. Yule (2007: 226) says "...variation in speech is an important and well-recognized aspect of our daily lives as language-users in different regional and social communities". The language of investigation here is English, as it is used in Christian religious circles in Nigeria. It is to see how Christian preachers manipulate the language for purposes such as convincing, persuading, entertaining, educating, informing, etc. Babatunde (1998: 49) has noted that "speakers introduce a number of stylistic and 
rhetorical devices in the development of their speeches. In one way or the other, the devices help to reinforce the true value of the claims they make so as to enable them persuade the audience".

Rhyme and rhythm, particularly in poetry, is a special use of language for special or specific effect. Children rhymes, for example, are important for their rhyme and rhythm rather than the message conveyed, if there is any. To this extent, our consideration of rhyme, rhythm and rhetoric in religious discourse here is the special effect to which preachers deploy language, in a way that "the plot, the characters, the wit, the passions, the descriptions are all exalted above the level of common converse, as high as the imagination of the [preacher] can carry them, with proportion to verisimility" (Daiches, 1974: 223).

The thrust of this study is the use of English in Christian religious discourse in Nigeria's second language English setting. Discourse is, here, conceived as written or spoken language, which Foucault, according to Griffith (2002: 132), claims to be "political" as "People with power-social, economic, political, or artistic-use discourses to manipulate other people and maintain their own power."

Although discourse is considered as "an extended verbal exchange on some topic, especially a conversation" (McLaughlin, 2006: 37) structurally organized, and adhering to cooperation principle, in this study, discourse is restricted to spoken speeches as sermons and Christian written texts.

\subsection{Literary Consideration of Christian Religious Discourse}

Apart from its primary status as a religious treatise, the Bible is a significant literary piece that can be enjoyed for its poetic beauty and value. It is to be noted that the book of Psalms in the Bible is full of elements of poetry, while a lot of rhetorical devices are evident in other books such as the Proverbs, Songs of Solomon and Ecclesiastes. This, no doubt, may have contributed to Christian preachers' poetic use of language in their communications. The literariness in Christian religious discourse is evident in the use of language, and language is the soul of every discourse. The special use of language by these preachers gives life and vitality to their sermons, helping them to drive their messages home as effectively and as pungently as possible. There is poetry in their sermons and their messages, making them literary. This is so, if we see poetry as literature and vice versa, and more particularly, if poetry is seen as "a quality of beauty or emotional power" (Oxford English Minidictionary). Also in the words of Reeves (1978: 17): "The desire to communicate, to express, to give voice to emotion, is the root from which all poetry springs" and to Coleridge, poetry is the best words in the best order.

Poetry is no longer the exclusive preserve of a class of people because of the esoteric use of language. As noted by Anozie, cited by Olu Obafemi (2011: 10), "poetry has ceased to be an exercise in learned and esoteric snobbery or privacy: it is henceforth a means of ...describing popular feelings and aspiration in the idiom of the people". This is exactly the case with the use of language that is more poetic than ordinary by Christian religious leaders in Nigeria, who now adopt poetry as a rhetorical device; exhibiting their skill with the English language to effectively persuade or influence people. Furthermore, Obafemi says "...the language of poetry differs from work-a-day language usage" (p. 14). These Christian preachers have realized this, and have also recognized the power of language and now avail themselves of the opportunity that language presents to reach their audience more. Like real poets, they deploy poetic language to rouse and ignite their listeners' awareness, resorting to rhetorical tactic, using language as a popular weapon for the enlightenment of their congregation.

\subsection{Research Objectives}

This study on the use of English in Christian religious discourse in Nigeria's ESL environment has the following objectives:

i. to examine the special use of English in religious discourse in Nigeria's ESL environment;

ii. to identify the various linguistic/literary devices prevalent in Nigeria's Christian religious discourse and

iii. to show the effects of this special use of English on the audience.

\subsection{Theoretical Framework}

With religious discourse considered as literary work, this study relies on both stylistic and pragmatic theories for more light. Wikipedia defines stylistics as the study of text interpretation from a linguistic point of view, linking literary criticism and linguistics. Pragmatics is defined by The American Heritage Dictionary of the English language (2000) as: "The study of language as it is used in a social context, including its effect on the interlocutors'. Further clarification considers pragmatics as "a subfield of linguistics which studies the ways in which context contributes to meaning." 
The choice of stylistics for this study was informed by the literary consideration of preachers' sermons and messages and because, according to Wikipedia: "The preferred object of stylistics studies is literature, but not "high literature" but other forms of written texts such as texts from the domain of advertising, pop culture, politics or religion". As the study of style, looking at this work from the stylistic prism, we see the individualism and creative use of language resources, as permitted by the user's period, genre and purpose (Spencer, 1971).

This kind of study cannot also but be hinged on pragmatics, because these preachers' use of language is in relation to religious context, and especially the effects the use of language has on the interlocutors. Context, to a large extent contributes to meaning, and with the listeners or readers pragmatic competence, they are able to understand preachers' intended meaning. In speech act analysis, the concept of MCB is usually at play in any socio-lingual interaction; this is why meaning is not lost in a preacher's use of language, no matter how special or seemingly esoteric.

Whenever language is used, the speech act theory holds that an action is being performed, and this may be classified as any of the following:

i. $\quad$ assertives, committing the speaker to the truth of the expressed proposition;

ii. directives, attempting to cause the addressee to do something;

iii. commissives, like directives, creating an obligation in the speaker, not in the hearer as is the case in directives;

iv. expressives, expressing the inner state of the speaker, without any alteration to the world order and

v. declaratives, with the concomitant effect of immediate change in the state of affairs.

The special use of English in Christian religious discourse in Nigeria's ESL environment can, therefore, be examined through the speech act theory, which attempts to explain the way speakers use language to accomplish their intention and how hearers infer the intended meaning from what is said.

\subsection{Scope of the Study}

This is not a study or analysis of any particular sermon or Christian discourse. Babatunde (1998) did that in a few sermons and Christian speeches. This study is an analysis of selected ingenious use of the English language by second language English users in religious discourse. The selections, from different sermons and Christian literatures are not narrowed down to specific sermons or speeches, as done by Babatunde. The reason for this departure is to show the widespread use of linguistic and literary devices among preachers in a second language environment. A look at some other Christian literatures, especially devotional materials from other countries does not show a visible use of these devices as done by this category of second language English users in Nigeria.

\section{Methodology}

This is a simple descriptive research aimed at examining the use of English in religious discourse in Nigeria's ESL environment. The methods used in gathering data include:

i. Personal observation as a participant observer in churches where sermons in which the data presented for this study were gathered were preached;

ii. Reading texts, in form of Christian literatures, devotional books, etc.

The researcher, in the course of data collection for this study, was always armed with writing materials to record those expressions that appeared to him outstanding use of the English language by second language users. This way, some identified expressions form the corpus for this study.

\subsection{Data Presentation and Analysis}

That preachers are poets is demonstrated by the use of language that is "above the level of common converse" (Daiches, 1974). Poetry, of all the literary genres, exhibits the use of literary devices the most, while of all other common discourses, religion demonstrates the use of these devices the most. The data presented below represent Christian religious preachers' uncommon use of language for specific purposes. These data will be analyzed into different linguistic as well as literary devices.

The data gathered are presented below with items for discussion highlighted in italics:

i. That is why you must abstain from every appearance of fornication or evil-because it sings before it stings like a deadly cobra!

ii. Weakholds and strongholds 
iii. A victory can turn the victor into a victim

iv. A journey from mystery to miracle/merriment

A journey from hopelessness to happiness

A journey from poverty to prosperity

A journey from captivity to conquering

A journey from death unto life

A journey from famine to feasting

A journey from rags to riches

v. Fresh fire from heaven

vi. Why do we have more politics than "powertics" in our churches?

vii. God's Riches At Christ's Expense (GRACE)

viii. False Experience Appearing Real (FEAR)

ix. Forsaking All I Trust Him (FAITH)

x. Preach[P]Reach $[R]$ each

xi. [D]evil

xii. [D]anger

xiii. It is an experience in which your fasting becomes an abomination to God and your fasting will fasten you to one spot.

xiv. Seven days without prayer make one weak.

xv. Know Christ know peace; No Christ no peace.

xvi. The church has become so worldly and the world so churchy, that you can hardly differentiate the church from the world.

xvii. Availability for Christian service is availing yourself of your ability.

xviii. Jacob at Jabbok

xix. God, in Philippians 4:19, says he will supply your need and not your greed.

$x x$. The church, today, needs more agonizers than organizers.

xxi. Proper preparation prevents poor performance.

xxii. Those who fail to plan actually plan to fail.

xxiii. Bad counsel leads to bad council that can cancel your destiny.

xxiv. Do not marry a man because of what he drives, but what drives him.

$x x v$. A family altar will alter your home for good.

The data above are just a few found captivating and selected for analysis by the researcher. They are regrouped into different language or literary devices as explained below.

\subsection{Personification}

a. That is why you must abstain from every appearance of fornication or evil-because it sings before it stings like a deadly cobra!

In this example, an abstraction, "fornication", is animated, having the power of a living thing and capable of singing, like human and stinging like a bee. The purpose of this is to warn the faithful of the danger involved in the sinful act of fornication. Apart from the literary weight of this data, as a directive act, hearers are not only given suggestion or request to quit the fornicating act but are also commanded to so do "you must abstain".

b. It is an experience in which your fasting becomes an abomination to God and your fasting will fasten you to one spot.

In the above example, there are two instances of special language use: personification and pun. Personification is evident in animating "fasting" as capable of holding down to a spot (fasten). The play on words is evident in the similar pronunciation in the two words "fasting" and "fasten". This is also a representative act because it is an 
assertion or a claim. As an assertion, the proposition here is believed to be true by the speaker's conviction. This is, however, subjective, and this assertion may be either true or false.

\subsection{Neologism}

We define, here, rhyme, rhythm and rhetoric as the special use and coinage of words and expressions for purposes aesthetic and functional in religious discourse. The word "weakhold" is non-existent in the English language, but it is formed here as an antonym of "stronghold". This is neologism which is a "new word...introduced into a language, by whatever process" (Matthews, 2005: 241). The process involved here is finding the opposite of the root "strong" in the word "stronghold". The meaning of the new word "weakhold" may, however, not be obvious if it is not contrasted with its antonym or used in context.

Another example of neologism from our data is "powertics" in the sentence:

Why do we have more politics than powertics in our churches?

The suffix of the new word is derived from the more common word "politics", which is conceived, in Nigeria, as unwholesome method of administering people or organization. The preacher is denouncing the practice of solving spiritual problem by secular method, rather than asking for God's power.

In yet another example, we have the word "agonizers", for those who will stand in the gap for the people in prayer, coined from its contrast, "organizers", in this sentence in our data:

The church, today, needs more agonizers than organizers.

Besides the neologism and the contrast in the two words, there is also rhyme and rhythm in them, as the end rhyme makes the sentence interesting and musical. These words are strange to the English vocabulary, but are potential words, especially "agonizers", which follows the normal word formation process of suffixation in English, and also considering the fact that the English language is open ended and can accommodate new words.

\subsection{Word Expansion}

In this category we have single words being expanded as if they were originally acronyms. Examples from our data include:

$$
\begin{array}{ll}
\text { i. } & \text { GRACE = God's Riches At Christ's Expense } \\
\text { ii. } & \text { FEAR = False Experience Appearing Real } \\
\text { iii. } & \text { FAITH = Forsaking All I Trust Him } \\
\text { iv. } & \text { SIN = Satan's Identity Number }
\end{array}
$$

The purpose of this expansion process is to drive home the importance of the word and its particular import on the Christian faith. In speech act, these data may be categorized as representatives to the extent that they are claims or assertions on the state of affairs carrying the true or false value.

\subsection{Letter Deletion}

The import of a word may be impressed on the Christian faithful through this process of deletion, which results into different words with a significant meaning and implication.

$$
\begin{array}{ll}
\text { i. } & \text { Preach }[\text { P]reach }[R] \text { each (Preach } \leftrightarrow \text { Reach } \leftrightarrow \text { Each) } \\
\text { ii. } & \text { Devil }[D] \text { evil (Devil } \leftrightarrow \text { Evil) } \\
\text { iii. } & \text { Danger [D]anger (Danger } \leftrightarrow \text { Anger) }
\end{array}
$$

From our data, we have the word "preach" becoming three words through a progressive process of deletion of initial letter. What the preacher is driving at, here, in the first example is that Christians should "preach" to "reach" "each" of the unreached outside the faith. In speech act, this is a directive act, giving command. In the second example, the preacher says the "devil" is just a [d] short of "evil" and that the devil has no good thing to offer, while in the third example, the preacher says "danger" is a [d] short of "anger" with the implication that a man full of anger is full of danger and so dangerous. Although this may not have been said, the hearer can infer it from the context. These last two can be categorized as representative acts as these are assertions and claims based on the speaker's belief, which may be subjective. 


\subsection{Antonym/Antithesis}

Antonym is "a sense relation which exists between words which are opposite in meaning, or sense" (Finch, 2000: 151), while antithesis is "a rhetorical device in which thoughts or words are balanced in opposition" (Thorne, 2006: 407). This seems to generate more rhythm in Christian religious discourse. Let us consider the following:

$>$ A journey from mystery to miracle/merriment

$>$ A journey from hopelessness to happiness

$>$ A journey from poverty to prosperity

$>$ A journey from captivity to conquering

$>$ A journey from death unto life

$>$ A journey from famine to feasting

$>$ A journey from rags to riches

Apart from the instances of antonyms/antithesis in the above data, there is also evidence of rhyme and rhythm and many cases of alliteration in some of the data. This is considering that rhythm, from its origin in a Greek word means "flow" (Reeves, 1978). Rhythm is a movement from one point to another in which there is recurrence of identical points with the major characteristic of repetition (Egudu, 1977: 34). In other words, "...rhythm can be created through repetition" (Thorne, 2006: 26). There is variety in the above data to confirm Egudu's (1977) observation that "repetition does not imply monotony, for there is also in rhythm that alternation which makes for variety" (p. 34). From the speech act point of view, our data will fall into commissives, as these are promises or offers, obligatory on the speaker, not the hearer as in the case of directives. Although the direct speaker, here, may not be the one offering the better alternatives, he stands in the gap, to offer those alternatives.

Rhythm, as a free flow and elegant choice and use of words as enhanced by repetition, can also be seen in the subsection of this Bible Study outline in one of the popular Pentecostal denominations in Nigeria:

i. The character and conduct of suffering saints

ii. The consecration and confession of suffering saints

iii. The conscience and confidence of suffering saints.

Apart from the obvious alliterative patterns, the repetition of suffering saints across the three subheadings engenders rhythm. This is the common rhythmical pattern of this Pentecostal denomination, week after week, showing that rhythm is not limited only to lexical choice, but extends to the structural arrangements of sermons or messages with subdivisions symmetrically and alliteratively arranged to make them memorable. Although we have said there is no visible use of the common devices used in Nigerian Christian discourse in other countries, example of alliterative use of language in Nigerian Christian discourse can be seen in the following from the popular Our Daily Bread, published in the United States of America:

Pleasure, power and possession are no substitutes for peace of heart and mind.

\subsection{Oxymoron}

This is a figure of speech that "combines two apparently contradictory elements" (Beaty, et al., 2002: A59). This is evident in the example:

Fresh fire from heaven

While fire is supposed to be hot, it is here expressed as fresh, a quality associated with objects raw and moist. In this case, fire and fresh are juxtaposed with the meaning of new anointing/power from heaven.

\subsection{Homophony}

This is a situation where two words are spoken identically as in soul and sole (Kuiper \& Allan, 2004: 56). The purpose of this device is to draw attention to the importance of homophonic words through sound similarity, as seen in our data below, where the similarity in sound is played upon in the words highlighted. The two words fasting and fasten are similar, when pronounced, at least to non-native speakers who hear them as the same in the example: 
a. It is an experience in which your fasting becomes an abomination to God and your fasting will fasten you to one spot.

Let us consider some other examples:

b. Seven days without prayer make one weak.

The sound in the word weak is identical to week, a period of seven successive days, to express the power in prayer, and the fact that staying without prayer for seven successive days will lead to spiritual weakness.

c. Know Christ Know peace; No Christ No peace.

Here, there is play on the similar sound in the two words highlighted to underscore the fact that having a knowledge of Christ guarantees peace, while on the contrary, having no knowledge of Christ is an invitation to crises.

d. A family altar will alter your home for good.

The implication of the above is that a regular time of prayer in the home is like raising an altar that is capable of making a positive change (alter) in the home.

From the speech act point of view, these examples are more of representatives as they are claims or assertions about the state of affairs in the world (Mey, 2001), based on the subjective views of the speakers, which may be true or false.

\subsection{Phony Rhyme}

\section{Jacob at Jabbok}

This is a confusing sameness of sounds, which actually do not rhyme, but sound as if they do. In a religious program, the theme was wrestling to secure your destiny, as done by Jacob at Jabbok (Genesis, 32: 24-29). The two words, ordinarily, appear and also tend to sound alike, but there is no real sound sameness in the two words. The two words when uttered together were, however, appealing and have expressive perlocutionary effect, capable of drawing attention.

\subsection{Word Order Reversal}

\section{Those who fail to plan actually plan to fail.}

In this example, the order of the highlighted words in the sentence is reversed to create a special effect of the need to avoid failure through lack of adequate planning. As this is more of promises and threats, this example is commissives, from the speech act point of view, committing to some future action.

\subsection{Pun}

Preachers also play on words to create special effect as seen in the following examples from our data:

\section{a. Bad counsel leads to bad council that can cancel your destiny.}

The major device used here by the preacher to drive home his point for the need for good counsel is pun. The similarity in the words played on is rhythmical and fanciful and thus capable of capturing the attention of the audience.

b. Do not marry a man because of what he drives, but what drives him.

This example plays on the word drive in the sentence. Apart from the pun, rhythm is also evident. The examples we discussed under homophony are also relevant here.

Table 1 that follows is a further analysis of linguistic, literary and rhetorical devices to know the frequency of occurrence, their perlocutionary effects and the audience's inference of intended meaning. 
Table 1. Summary of frequency of use of linguistic, literary and rhetorical devices

\begin{tabular}{lcll}
\hline $\begin{array}{l}\text { Linguistic, literary and } \\
\text { rhetorical devices }\end{array}$ & $\begin{array}{c}\text { Frequency } \\
\text { in the data }\end{array}$ & $\begin{array}{l}\text { Perlocutionary } \\
\text { effect in the } \\
\text { context }\end{array}$ & Audience's inference of the intended meaning \\
\hline Personification & 2 & $\begin{array}{l}\text { Directives (1) } \\
\text { Assertives (1) }\end{array}$ & To take an immediate action. \\
Neologism & 3 & Declaratives & $\begin{array}{l}\text { To call attention to anomalies that need to be changed } \\
\text { in Christian worship. }\end{array}$ \\
Word expansion & 4 & Expressive & $\begin{array}{l}\text { To drive home the importance of the words and show } \\
\text { their particular import on the Christian faith. } \\
\text { Letter deletion }\end{array}$ \\
To obey God's command to preach to all
\end{tabular}

In all, the data used comprised 25 items extracted from 11 Christian literatures, especially daily devotionals published in Nigeria's second language English environment and 14 sermons. From the data, it is obvious that "word expansion" and "homophony" have the highest frequency of use with the intention of driving home important messages that will cause a change in the audience. The high level of neologism is an attempt by second language English users to domesticate the language and make it more relevant and useful in their own immediate environment, while at the same time not seriously jeopardizing mutual intelligibility.

\section{Effects/Purposes of Rhyme, Rhythm and Rhetoric in Christian Religious Discourse}

Words are powerful and more so in the hands of those who are good at skillfully deploying them. Words, when carefully used, can be a major means of getting people's attention and getting them to do something or take a course of action. Preachers, in the Christian faith, try to appeal to their congregation through the free flow of words and sentences in a manner that will:
a. make the congregation attracted and committed;
b. serve as a means of emphasis and easy remembrance and recall;
c. call for a decision to be taken and
d. ensure musicality and enjoyment.

Rhythm is life and life is rhythmical as life is lived in alternation.

\section{Conclusion}

From the way the English language is used as discussed in this study, from both literary and linguistic points of view, making recourse to speech act theories, the following can be deduced that:

i. Christian religious leaders and preachers recognize the power of language in persuading, enticing, promising, asserting, threatening etc, and so specially deploy language to achieve these purposes, 
through the use of "choice word and measured phrase, above the reach/Of ordinary men" (Wordsworth);

ii. Christian religious leaders consciously or unconsciously adopt rhetorical devices such as personification, oxymoron, pun, homophony, rhyme and rhythm, etc and also event new words not currently existing in the English language to serve their own communicative and aesthetic purposes, thus confirming Babatunde's (1998) submission that rhetorical features are used by speakers and by extension writers to serve ornamental functions of enhancing the aesthetic quality of speakers, in addition to assisting in conveying speakers' intended meaning and

iii. the special use of English in Christian religious discourse, from the point of view of speech act theory, is used to give commands and suggestions by way of directives; make claims and assertions by way of representatives and make promises and issue threats by way of commissives.

From the findings in this study, we can conclude that with the way the English language is used in Christian religious discourse in Nigeria, the emerging new Nigerian English will soon become a global reality that will turn out to be a major variety of English in the world. It is becoming more obvious from the data presented in this study that English is taking on a life of its own in Nigeria, the world's second largest ESL country, such that as there are today varieties of English such as Singaporean English "Singlish" and Spanish English "Spanglish", Nigerian English, "Niglish" may soon become a global reality.

\section{References}

Akere, F. (2009). The English Language in Nigeria: The Sociolinguistic Dynamics of Decolonization and Globalization. In Reinventing the English Language in Nigeria in the Context of Globalization and Decolonization. Refereed Proceedings of the 23rd Annual Conference of the English Studies Association (NESA). Lagos: Olivetree PublishingVenture.

Babatunde, S. T. (1998). Persuasion in Christian Religious Speeches-A Speech Act Analysis. Studies in Stylistics and Discourse Analysis, 1, 45-56.

Beaty, J., Booth, A., Hunter, J. P., \& Mays, K. J. (2002). The Norton Introduction to Literature (8th ed.). New York, London: W. W. Norton \& Company.

Coleridge, S. T. (1827). Table Talk-July 12, 1827. In Bartlet, J. (Ed.), Familiar Quotations. Boston and Toronto: Little Brown and Company.

Daiches, D. (1974). Critical Approaches to Literature. London: Longman.

Egudu, R. N. (1977). The Study of Poetry. Ibadan, Nigeria: Oxford University Press.

Finch, G. (2000). Linguistic Terms and Concepts. Houndmills, Basingstoke, Hampshire: Palgrave Macmillan.

Griffith, K. (2002). Writing Essays about Literature (6th ed.). Thomas Wadsworth.

Jowitt, D. (2009). English Language Teaching: A View from the Millennium. Lead paper presented at the 7th National Conference of the National Association of Teachers and Researchers in English as a Second Language, Federal Polytechnic, Nasarawa, Nigeria, 6-9 October.

Kuiper, K., \& Allan, W. S. (2004). An Introduction to English Language (2nd ed.). Palgrave Macmillan.

Matthews, P. H. (2005). Oxford Concise Dictionary of Linguistics. Oxford: Oxford University Press.

McLaughlin, S. (2006). Introduction to Language Development (2nd ed.). Australia: Thomson Delmar Learning.

Mey Jacob, L. (2001). Pragmatics (2nd ed.). Blackwell Publishing.

Obafemi, O. (2011). Language and literature as anvil of political consciousness. Keynote address at the International Conference of the National Association of Students of English and Literary Studies. Ahmadu Bello University, Zaria, Nigeria.

RBC Ministries. (2012). Our Daily Bread. Grand Rapids, Michigan, USA.

Reeves, J. (1978). Understanding Poetry. London: Pan Books Ltd.

Spencer, J. (1971). Introduction. In Enkvist, N. E., Spencer, J., \& Gregory, M. J. (Eds.), Linguistics and Style. London: Oxford University Press.

Thorne, S. (2006). Mastering Poetry. Palgrave Macmillan. 
Wordsworth, W. (1980). Resolution and Independence, Stanza 14. In Bartlet, J. (Ed.), Familiar Quotations. Boston and Toronto: Little Brown and Company.

Yule, G. (2007). The Study of Language (2nd ed.). Cambridge: Cambridge University Press. 